\title{
Studies on epidemiology of Alternaria blight of marigold (Tagetes erecta L.) in Madhya Pradesh
}

DHIRENDRA SINGH BHADOURIA

Department of Plant Pathology, College of Agriculture, Rajmata Vijayaraje Scindia Krishi Vishwavidyalaya, GWALIOR (M.P.) INDIA

\section{ARITCLE INFO}

Received : 29.09 .2014

Revised : 09.09 .2015

Accepted : 23.09 .2015

\section{KEY WORDS :}

Marigold, Tagetes erecta, Epidemiology, Altrernaria blight

Author for Correspondence :

Email: dhirendrabhadouria@gmail.com

\begin{abstract}
The present studies were carried out during winter season at college of Agriculture, Gwalior to investigate the epidemiology of Alternaria blight of marigold. The per cent disease intensity of leaf spot in the surveyed localities of Gwalior, Morena and Bhind districts was in the range of 20.2 (Ghatigaon) to 40.6 (Akbarpur), 20.4 (Porsa) to 30.2 (Joura) and 10.8 (Roan), 27.4\% (Mehgaon), respectively. The intensity of flower blight per cent in the locations of above three districts was in the range of 23.3 (Utila) to 44.0 (Akbarpur) 26.6 (Ambah) to 32.2 (Joura) and 13.2 (Roan) to 20.0 per cent (Atter). The maximum intensity of leaf spot was recorded in Gwalior district (28.65\%) followed by Morena (25.31\%) and Bhind (16.85\%). Similar to leaf spot the maximum intensity of flower blight was also recorded in Gwalior (31.61\%) followed by Morena $(29.26 \%)$ and Bhind (17.01\%). The oil extracts of Neem and Eucalyptus @ 5 per cent and leaf extracts of Neem and Eucalyptus @ 20 per cent were found very effective against A. tagetica under in vitro condition. Regression study reveals that with one per cent. Regression study also reveals the 52.65 per cent seed germination under disease free condition and thereafter it decreases by 0.638 per cent with unit increase ( $1 \%$ each) in the intensity of flower blight.
\end{abstract}

How to view point the article : Bhadouria, Dhirendra Singh (2015). Studies on epidemiology of Alternaria blight of marigold (Tagetes erecta L.) in Madhya Pradesh. Internat. J. Plant Protec., 8(2): 368-371. 